DOI: https://doi.org/10.24127/ajpm.v10i2.3569

\title{
ANALYSIS OF STORY PROBLEMS BY APPLYING THE PROBLEM BASED LEARNING BASED ON NEWMAN'S ERROR ANALYSIS
}

\author{
Yuliana $^{1}$, Marhan Taufik ${ }^{2}$, Reni Dwi Susanti ${ }^{3 *}$ \\ 1,2,3* Pendidikan Matematika, Universitas Muhammadiyah Malang, Malang, Indonesia \\ * Corresponding author. Jl. Raya Tlogomas No. 246, 65144, Malang, Indonesia

E-mail: $\frac{\frac{\text { yuli061297@gmail.com }}{\text { marhan@umm.ac.id }}{ }^{2)}}{\underline{\text { renidwi@umm.ac.id }}^{3 *)}}$

Received 17 February 2021; Received in revised form 26 June 2021; Accepted 03 July 2021

\begin{abstract}
This study aims to describe the application of the Problem Based Learning (PBL) learning model in mathematics learning, to find out the types of errors that students make in solving math story problems based on Newman's analysis, and what factors are the causes of student errors in solving math story problems. The subjects of this research were students of class VII. The type of research used in this research is descriptive qualitative. Data collection techniques used in this research are observation, written tests, and interviews. Data analysis is done by reducing research data, presenting data and drawing conclusions. The results showed that learning with the application of the PBL model with Newman Error Analysis (NEA) on the rectangular material went very well during the three meetings that went very well, as indicated by the implementation of each of these learning steps during the learning process going well, this indicates that student activities when the learning process by applying the PBL learning model with the NEA went very well. The error analysis based on the NEA shows that the most mistakes made by students were errors in writing the final answer. This was due to students' mistakes in working on the previous stage and also students who did not write conclusions, the lowest error made by students was transformation errors.
\end{abstract}

Keywords : Newman analysis; problem based learning; story problems.

\begin{abstract}
Abstrak
Penelitian ini bertujuan untuk mendeskripsikan penerapan model pembelajaran Problem Based Learning (PBL) pada pembelajaran matematika, mengetahui jenis kesalahan yang dilakukan siswa dalam menyelesaikan soal berbentuk cerita matematika berdasakan analisis newman, dan faktor-faktor apa saja yang menjadi penyebab terjadinya kesalahan siswa dalam menyelesaikan soal cerita matematika. Subjek penelitian ini adalah siswa-siswi kelas VII. Jenis penelitian yang digunakan pada penelitian ini yaitu deskriptif kualitatif. Teknik pengumpulan data yang digunakan dalam penelitian ini yaitu menggunakan observasi, tes tertulis dan wawancara. Analisis data yang dilakukan adalah dengan cara mereduksi data hasil penelitian, penyajian data dan penarikan kesimpulan. Hasil penelitian menunjukkan bahwa pembelajaran dengan penerapan model PBL dengan Newman Error Analysis (NEA) pada materi segiempat berlangsung dengan sangat baik selama tiga kali pertemuan ditunjukkan dari keterlaksanaan masing-masing langkah pembelajaran tersebut selama proses pembelajaran berlangsung berjalan dengan baik, hal ini menandakan bahwa aktivitas siswa ketika proses pembelajaran dengan menerapkan model pembelajaran PBL dengan NEA berlangsung dengan sangat baik. Analisis kesalahan berdasarkan NEA menunjukkan bahwa kesalahan paling banyak yang dilakukan siswa adalah kesalahan penulisan jawaban akhir hal ini disebabkan kesalahan siswa dalam mengerjakan tahap sebelumnya dan juga siswa yang tidak menuliskan kesimpulan, kesalahan terendah yang dilakukan siswa adalah kesalahan transformasi.
\end{abstract}

Kata kunci: Analisis Newman; problem based learning; soal cerita.

This is an open access article under the Creative Commons Attribution 4.0 International License 
DOI: https://doi.org/10.24127/ajpm.v10i2.3569

\section{INTRODUCTION}

One of the factors that determine the quality of human resources is education (Yusri, 2018). Therefore education in Indonesia has repeatedly undergone improvements and improvements in its curriculum. As stated by (Yusri, 2018) efforts to improve the quality of education, especially in mathematics learning, are carried out by implementing the 2013 curriculum which is expected to run optimally. Mathematics is a subject that relates to the real world and can be applied in various fields, but learning mathematics in schools is more procedural in nature and requires a lot of practice, therefore many students become inactive in class and only accept lessons delivered by teachers ( $\mathrm{Li}$ \& Schoenfeld, 2019) (Mustaffa et al., 2016). According to (Mustaffa et al., 2016), the mathematics literaturer shows that Problem Based Learning (PBL) is a learning approach that can stimulate student thinking. So as an effort to overcome student difficulties in solving math problems, teachers can apply the PBL model that can help students to think critically and be actively involved in by linking math problems and everyday life. PBL is learning based on problems, where students will not only get basic knowledge in the classroom, but also be able to apply this basic knowledge to solve problems in everyday life (Bilgin et al., 2009) (Selçuk, 2010).

The characteristics of achieving a mathematics learning can be seen from the final score of student success in solving math problems, this can be seen by evaluating student learning outcomes by holding written tests. Based on the PISA (Program for International Student Assessment) Indonesia's mathematics ranking in 2018 is still far below Singapore, which is in the first rank, where Indonesia is still ranked 63 out of 70 countries (Sholeh \& Sari, 2018). Based on the PISA data that has been described, it can be seen that students in Indonesia still have less solving abilities. One of the most important parts of the mathematics curriculum is a problem-solving ability (Yusri, 2018). Students must have skills in solving problems (Sipayung \& Anzelina, 2019). However, most students are still unable to solve math problems in the form of story problems, this can be seen from the PISA data that has been previously described.

Apprenticeship activities carried out at SMAN 8 Malang in class VII MIPA 4 material on Three Variable Linear Equation Systems (SPLTV), where provide explanations related to SPLTV material with various forms of completion and a variety of questions, starting from questions in the form of mathematics to questions that are related to everyday life that is formed in the problem of the story, most students complain when given story questions because they feel confused about changing the mathematical form. The mistakes made by students in solving story problems are not understanding the meaning of the problem, unable to determine what is known in the questions, as well as errors in the problem-solving process so that many are wrong in concluding, therefore to find out students' mistakes In solving math problem problems, analysis is necessary

The Newman error analysis stage is one of the appropriate error analysis stages and can be used in story problems ( $R r$ Chusnul et al., 2017) (Rahayuningsih \& Qohar, 2014). (Haryati et al., 2016) also suggest that in solving the problem of story 
problems with the Newman analysis method, five stages can determine the mistakes that students might make, while the stages are reading (students' understanding of words or symbols contained in questions), comprehension), transformation, process skills, and encoding.

Based on the results of research conducted by (Rahayuningsih \& Qohar, 2014), the types of mistakes Newman made by students were errors in understanding the problem, transformation, process skills, and writing answers. and research conducted by (Tawfik \& Lilly, 2015) on PBL-based learning shows that PBL can improve students' thinking and skills in solving problems needed to meet educational needs.

Based on the description that has been described above, it shows that PBL has a good enough impact on students to solve mathematical problems, some studies show students' mistakes in solving story problems based on Newman's analysis, therefore researchers want to study the Analysis of Student Errors in Solving Mathematical Story Questions by Applying the PBL Learning Model Based on Newman's Error Analysis (NEA), so that this study aims to describe the application of the PBL learning model in mathematics learning, and what types of errors students make in solving problems in the form of math stories based on Newman analysis, and factors. -what factors cause student errors in solving math story problems.

\section{METHODS}

This type of research used in this research is qualitative research with a descriptive approach. The subjects of this study were seventh-grade students of junior high school who came from 2 different schools, the subject selection was carried out by gathering seventhgrade junior high school students at the Al-Akbar Foundation in Lombang village, Batang-Batang district, Sumenep Madura district, to analyze student errors based on NEA, the subject of which taken are 6 students from students with high, medium, low ability. There are three stages in this research, namely the stage of preparation, implementation, and data analysis.

Data collection techniques used in this study are observation, tests, and interviews. Observations were made to observe how the learning process by applying the PBL model to learning mathematics in class, at this stage also aims to observe student activity during learning, the test used is in the form of math story questions, in its completion students are expected to be able to work on and complete the test according to the stages Newman, Each step in solving the problem will be analyzed based on the Newman analysis to find out the mistakes of students in solving math story questions. This interview was conducted on several students who had been previously selected based on the students' ability categories, namely the low, medium, and high. The results of this interview are used to strengthen the data from the test results regarding the mistakes made by students and the factors that cause these errors.

The instruments used were student activity observation sheets, test sheets, and interview guidelines and data analysis techniques in this study, there were 3 stages, namely data reduction, data presentation, and conclusion drawing. The data reduction stages in this study provide an overview of (1) the application of PBL learning with NEA, while the reduced data is (1) 
calculating the number of student activity observation sheet scores that have been filled in with the observer from the first to the third meeting, then the value is calculated and categorized based on assessment criteria. correcting the results of the students' written test answers which were then taken by 6 students with 2 students each from the high, medium and low group categories, as well as conducting interviews with the 6 students who had been previously selected (3) Determining the percentage of the types of student errors on each question quadrilateral material math story. To find out what percentage of the types of errors made by students in solving rectangular problems. The stages of presenting the data in this study were (1) presenting the student activity observation sheet from the first to the third meeting in the form of a table and then narrating the student activity observation sheet from the table, (2) analyzing the results of student answers based on the NEA then describing the types of student errors in solve math story problems according to the NEA.

\section{RESULT AND DISCUSSION}

The implementation of learning by applying the PBL learning model with NEA on rectangular material in class VII at the Al-Akbar Santoso Lombang Foundation takes place in 3 stages, namely introduction, core, and closing. In the preliminary activity, the teacher opens the lesson by saying greetings and praying, then checks the attendance of students. After that, the teacher provides an outline of the material to be studied and informs the learning to be carried out. In the core activities, the teacher carries out PBL steps with the NEA, namely 1) giving orientation to the problem (reading problems); 2) organize students, namely the teacher directs students to make small groups; 3) Gather information with small groups; 4) Resolving problems; 5) Present and correct; 6) Evaluating. In the closing activity, the teacher re-checks the results of each group's discussion and the teacher reminds the material to be studied at the next meeting, then the teacher closes the lesson by praying and greeting. The results of observations of student activities during the learning took place from the first meeting to the third meeting which was filled by 2 observers, namely fellow researchers and researchers themselves, then each meeting was carried out by calculating the number of scores, after that, they were categorized according to the assessment criteria as a Table 1 .

Table 1. Student activity observation results

\begin{tabular}{|c|c|c|c|c|c|c|}
\hline \multirow{3}{*}{ Student Activity Indicators } & \multicolumn{6}{|c|}{ Meeting } \\
\hline & \multicolumn{2}{|c|}{1} & \multicolumn{2}{|c|}{2} & \multicolumn{2}{|c|}{3} \\
\hline & 1 & 2 & 1 & 2 & 1 & 2 \\
\hline Orientation & & & & & & \\
\hline $\begin{array}{l}\text { Students understand the learning objectives, and identify real math } \\
\text { problems. } \\
\text { Organizing Students }\end{array}$ & 3 & 3 & 3 & 3 & 4 & 4 \\
\hline $\begin{array}{l}\text { Students gather with small groups that are determined and listen to the } \\
\text { rules of the discussion, then have discussions with the group according } \\
\text { to the teacher's instructions. }\end{array}$ & 4 & 4 & 4 & 4 & 4 & 4 \\
\hline Gathering Information & & & & & & \\
\hline $\begin{array}{l}\text { Students arrange what they know and don't know and analyze the } \\
\text { problems they want to solve based on the problems in the LKK. }\end{array}$ & 3 & 2 & 3 & 4 & 4 & 4 \\
\hline
\end{tabular}


DOI: https://doi.org/10.24127/ajpm.v10i2.3569

\begin{tabular}{|c|c|c|c|c|c|c|}
\hline \multirow{3}{*}{ Student Activity Indicators } & \multicolumn{6}{|c|}{ Meeting } \\
\hline & \multicolumn{2}{|c|}{1} & \multicolumn{2}{|c|}{2} & \multicolumn{2}{|c|}{3} \\
\hline & 1 & 2 & 1 & 2 & 1 & 2 \\
\hline $\begin{array}{l}\text { Solving Problems } \\
\text { Students work on the problems faced systematically. } \\
\text { Presenting And Correcting }\end{array}$ & 3 & 3 & 3 & 3 & 4 & 4 \\
\hline $\begin{array}{l}\text { Students design and prepare materials to reinforce the presentation and } \\
\text { proofread their answers. }\end{array}$ & 2 & 2 & 3 & 3 & 4 & 3 \\
\hline $\begin{array}{l}\text { Evaluate } \\
\text { Students and teachers evaluate the information they have obtained. }\end{array}$ & 4 & 4 & 4 & 4 & 4 & 4 \\
\hline Total score & 19 & 18 & 20 & 21 & 24 & 23 \\
\hline Average of Each Observer (\%) & 79 & 75 & 83 & 87,5 & 100 & 96 \\
\hline Average Score of Each Meeting (\%) & 77 & & 85 & & 98 & \\
\hline Overall Activity Average (\%) & 87 & & & & & \\
\hline
\end{tabular}

Based on the results presented in the table 1 shows that the results of observations of student activity from the first meeting to the last meeting have increased with an average final score of $87 \%$, at the beginning of the meeting in the application of the PBL learning model with NEA students are still not familiar with the learning model that is applied because when in school students are accustomed to conventional learning and the PBL model with NEA is for the first time being applied so that some students still feel confused and unfamiliar with the implementation of learning with the PBL model, then at the meeting of the two students have started to get used to PBL learning but not maximally and at the last meeting they were already familiar with the applied learning so that at the last meeting the implementation of PBL learning with NEA went very well, this indicates that student activities when The learning process by applying the
PBL learning model with NEA is going very well, and students do not experience difficulties with the application of the PBL learning model with NEA. This is inversely proportional to research conducted by (Tarmizi \& Bayat, 2010; Tawfik \& Lilly, 2015) which states that in the application of PBL learning some students experience difficulties in a group and independent learning.

The mistakes made by students in solving math story problems on quadrilateral based on the NEA consisted of 6 students to become research subjects which were categorized into 3 categories, namely high, medium, and low-grade students. Respectively. Each category has 2 students, namely 2 students with highvalue categories $\left(\mathrm{S}_{1}\right.$ and $\left.\mathrm{S}_{2}\right)$, students from medium-value categories $\left(\mathrm{S}_{3}\right.$ and $\left.\mathrm{S}_{4}\right)$ and students from low categories $\left(S_{5}\right.$ and $\left.S_{6}\right)$ are as follows on Table 2.

Table 2. Student error percentage

\begin{tabular}{lcccccccc}
\hline \multirow{2}{*}{\multicolumn{1}{c}{ Type of error }} & \multicolumn{9}{c}{ Many Students Make Mistakes on } & \multirow{2}{*}{ Questions } & Total & Percentage \\
\cline { 2 - 7 } & $\mathbf{1}$ & $\mathbf{2}$ & $\mathbf{3}$ & $\mathbf{4}$ & $\mathbf{5}$ & & \\
\hline Reading Error & 1 & 4 & 4 & 2 & 3 & 14 & $46,6 \%$ \\
Error Understanding the Problem & 1 & 4 & 4 & 2 & 3 & 14 & $46,6 \%$ \\
Transformation Error & - & - & 3 & - & - & 3 & $10,0 \%$ \\
Process Skill Error & 1 & 4 & 3 & 3 & 3 & 14 & $46,6 \%$ \\
Encoding Error & 1 & 4 & 4 & 4 & 2 & 15 & $50,0 \%$ \\
\hline
\end{tabular}


DOI: https://doi.org/10.24127/ajpm.v10i2.3569

Based on Table 2, it can be seen that the lowest error lies in the transformation error, this is because, at the reading and understanding stage of the problem, the process skills and writing of the final answer of the students are not careful in writing the unit of length, even many students do not write the long unit. While the biggest mistake lies in the error in writing the final answer, this is due to making mistakes in the previous stage so that at the stage of writing the final answer students cannot write conclusions or the final answer that is correct and correct.

\section{Reading Error}

The student who made reading errors with an average percentage of reading errors of $46.6 \%$, based on this percentage, the students' reading errors were quite high. At the reading error stage, students experience errors in interpreting the symbols and sentences contained in the questions correctly and students cannot read the information contained in the questions completely. One example of reading errors made by students is the error made by $S_{6}$ in question no. 2, like in a Figure 1.

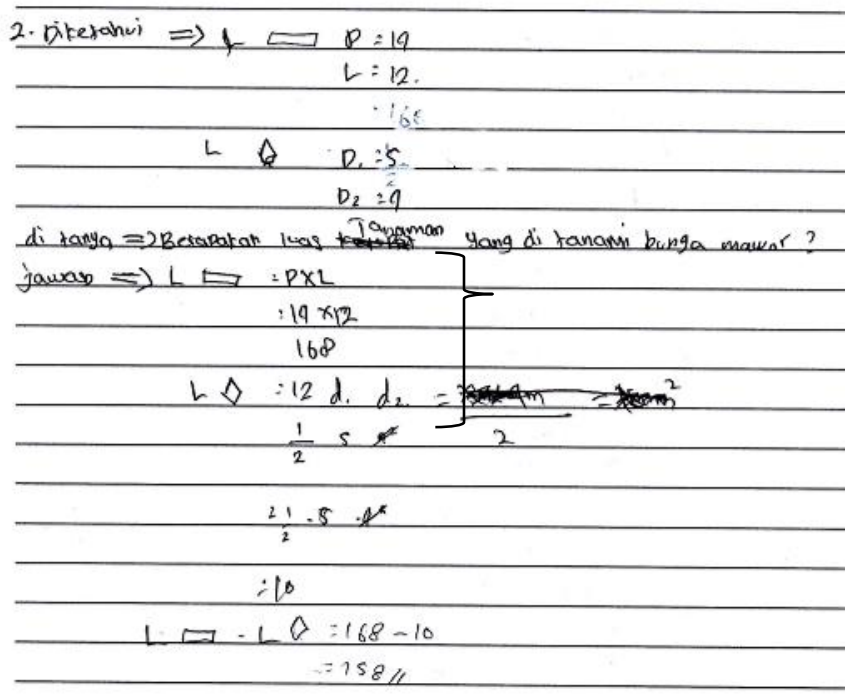

Figure 1: Error reading problem
In Figure 1, which has been described, it can be seen that the reading error made by $\mathrm{S}_{6}$ is not reading the symbols and information contained in the questions completely. In the questions given, the students were asked to determine how large the garden was to be planted with roses, but the students did not read the symbol in the question, the $\mathrm{m}$ symbol, so that until the end of the work the students did not have this symbol where it should have been in the final answer the symbol used was $\mathrm{m}^{2}$ because what is requested is a garden area. Based on the results of student answers and interviews with $\mathrm{S}_{6}$ on question No. 2, it can be concluded that $\mathrm{S}_{6}$ can read the information in the questions, but $S_{6}$ is not careful in reading the symbols contained in the questions. This is by the research conducted by Khaidir and Rahmi (2016) which states that students cannot go through the problem reading stage well, even though students can read problems well and have no difficulty. 
DOI: https://doi.org/10.24127/ajpm.v10i2.3569

\section{Comprehension Error}

Based on the results of the analysis in the previous table it can be seen that there are some students misunderstand the problem with an average percentage of errors in understanding the problem of $46.6 \%$, based on this percentage it can be categorized that the error in understanding the student's tenure is high. In the misunderstanding of this problem, some students were incomplete in writing what was known and what was asked in the questions, some students only wrote what was known but did not write down what was asked. One of the mistakes made by students in understanding the problem was one of the mistakes made by $S_{5}$, like in a Figure 2.

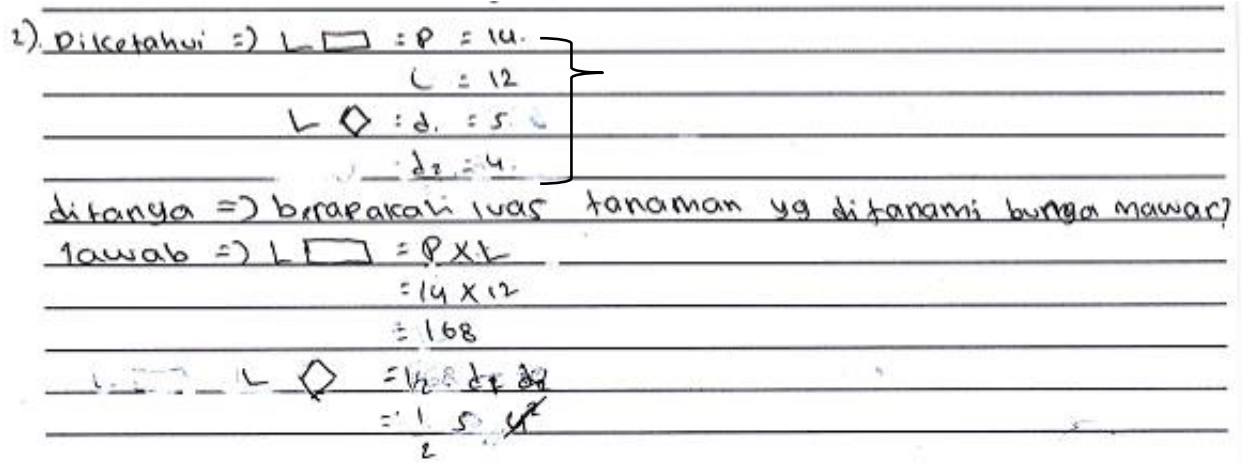

Figure 2. Misunderstanding the problem

In Figure 2, which has been described, it can be seen that the error in understanding the problem that was carried out by $\mathrm{S}_{5}$ was writing what was known to be but it was not right where $\mathrm{S}_{5}$ wrote what was known to be $\mathrm{p}=14,1$ $=12, d \_1=5$, and d_2 $=4, \mathrm{~S} \_6$ did not write units of length when writing the known information, $\mathrm{S} \_5$ should write $\mathrm{p}=$ $14 \mathrm{~m}, 1=12 \mathrm{~m}, \mathrm{~d} \_1=5 \mathrm{~m}$, and d $\_2=4 \mathrm{~m}$. Based on the results of tests and interviews with $S_{5}$ on question No. 2 , it can be concluded that the error made by $\mathrm{S}_{5}$ was due to the inaccuracy in solving the problems and considers what is written in the part in question is not used as assessment material. This is by research conducted by (Susanti \& Taufik, 2019), which is one of the mistakes in understanding the problem, namely students writing what they know and ask but is incomplete and some students write what is known but not quite right.

\section{Transformation Error}

Based on the results of the analysis in the table in the previous discussion, it can be seen that the average percentage of transformation errors is $10 \%$. Based on this percentage, it can be seen that the transformation error is relatively low compared to the error in reading and understanding the problem. This transformation error is caused by students who can understand what is being asked in the questions but fail to determine the formula to solve the problems in the questions, this transformation error will affect further errors, namely errors in processing skills and writing the final answer. One of the mistakes made by students in transformation is one of the mistakes made by $\mathrm{S}_{3}$ like a Figure 3 . 
In Figure 4, which has been described, it can be seen that the error of processing skills carried out by $\mathrm{S}_{4}$, namely $\mathrm{S}_{4}$, did not write the length unit at the process skills stage and also the result of the calculation of the length unit used should be $\mathrm{m}^{2}$, not $\mathrm{cm}^{2}$ so that in writing the final answer $\mathrm{S}_{4}$ also made a mistake. Based on the results of tests and interviews with $\mathrm{S}_{4}$ on question No. 2 , it can be concluded that the errors made by $\mathrm{S}_{4}$ were due to the inaccuracy and inaccuracy of $\mathrm{S}_{4}$ in solving problems in the problem and consider the length unit if it was not written in the process skills section and the length unit error in the calculation results was not considered an assessment material. This is in line with the results of research conducted by (Rahmawati \& Permata, 2018) that the error in process skills is that students are can identify suitable operations, but do not know the steps needed to carry out this operation perfectly.

\section{Encoding Error}

Based on the results of the analysis that has been presented in the table, it can be seen that the error in writing the final answer is the highest error among the other errors, which is equal to $50 \%$, the error in writing the final answer is caused because the student has solved the problem correctly but did not write the answer meant by the question. correct or not write the conclusion of the final answer to the problem. One of the mistakes made by students in transformation is one of the mistakes made by $S_{4}$, shown in the Figure 5.

In Figure 5, which has been described, it can be seen that the error in writing the final answer made by $\mathrm{S}_{4}$, namely $\mathrm{S}_{4}$, has resolved the problems contained in the questions correctly, namely the cost of making a fence of Rp. $520,000.00$ but $S_{4}$ did not write the conclusion requested on the question. Based on the results of tests and interviews with $\mathrm{S}_{4}$ on question No. 3 , it can be concluded that the error made by $\mathrm{S}_{4}$ was due to the inaccuracy and inaccuracy of $\mathrm{S}_{4}$ in writing the conclusion of the final answer to the problem. This is by the results of research by (Santoso et al., 2017) which state that the error in writing the final answer is unfortunate because students have succeeded in reaching the data processing stage but failed to write the final answer according to the conclusion.

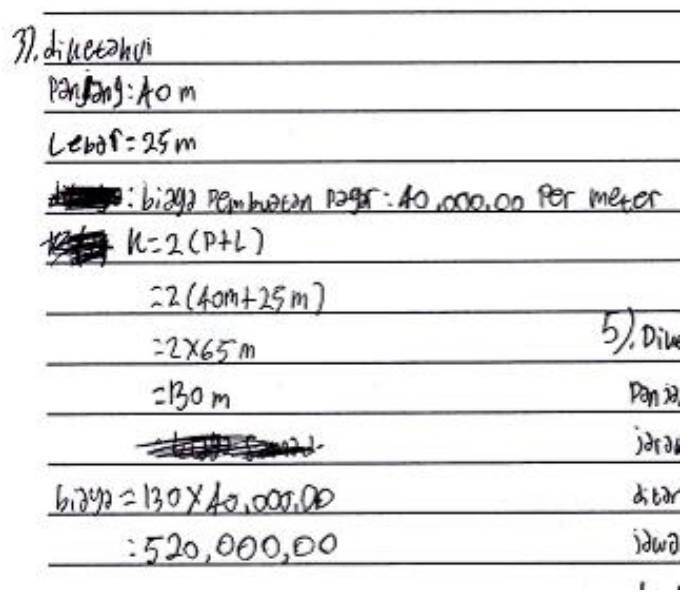

Figure 5: Errors in writing the final answer

Based on the discussion of the mistakes made by students in solving math story problems based on the NEA, the highest errors made by students were in the final answer writing error, namely $50 \%$ while the lowest error was in the transformation error which was $10 \%$, this is not in line with the research conducted. by (Rohmah \& Sutiarso, 2018) wherein this study the highest error lies in the transformation error while the lowest error lies in the reading error of the problem. This is different because this research does not write a 
conclusion because it assumes that the final result adequately represents what is asked in the question. Whereas in Transformation it is caused by students can understand what is being asked in the problem but fail to determine the sequence of operations to solve the problem correctly.

\section{CONCLUSION AND SUGGESTION}

Based on the results of research that has been carried out by applying the PBL model with NEA on quadrilateral material for three meetings in accordance with the steps that have been planned in the RPP, based on the results of the research, the implementation of PBL learning with NEA for three meetings goes very well, as shown from the implementation each of these learning steps during the learning process went well, which indicated that student activities during the learning process by applying the PBL learning model with NEA were going very well.

Based on the results of the research and discussion that has been previously described, it can be seen that the types of mistakes that students make in solving math story problems based on the NEA, the most mistakes made by students are mistakes in writing the final answer, this is due to mistakes in the previous stage which resulted in errors. in writing the final answer and also because students did not write down the final answer conclusions, and the lowest error that students made was a transformation error, this is because students were able to determine methods or formulas to solve problems, but many students did not write long units at this stage. write down information and also at the process skills stage so that in writing the final answer many students make mistakes.
Based on the results of these studies, in order to improve learning and also further research, the advice that can be given is that teachers must develop learning models in schools so that students do not feel bored and also students must also be accustomed to practice in solving story problems so that students can get used to working on story questions structured.

\section{REFERENCES}

Bilgin, I., Şenocak, E., \& Sözbilir, M. (2009). The effects of problembased learning instruction on university students' performance of conceptual and quantitative problems in gas concepts. Eurasia Journal of Mathematics, Science and Technology Education, 5(2), 153-164. https://doi.org/10.12973/ejmste/752 67

Haryati, T., Suyitno, A., \& Junaedi, I. (2016). Analisis Kesalahan Siswa SMP Kelas VII dalam Menyelesaikan Soal Cerita Pemecahan Masalah Berdasarkan Prosedur Newman. Unnes Journal of Mathematics Education, 5(1), 815.

Li, Y., \& Schoenfeld, A. H. (2019). Problematizing teaching and learning mathematics as "given" in STEM education. International Journal of STEM Education, 6(1). https://doi.org/10.1186/s40594019-0197-9

Mustaffa, N., Ismail, Z., Tasir, Z., \& Said, M. N. H. M. (2016). The Impacts of Implementing Problem-Based Learning (PBL) in Mathematics: A Review of Literature. International Journal of Academic Research in Business and Social Sciences, 6(12), 490-503. https://doi.org/10.6007/ijarbss/v6i12/2513 
Rahayuningsih, P., \& Qohar, A. (2014). Analisis Kesalahan Menyelesaikan Soal Cerita Sistem Persamaan Linear Dua Variabel (SPLDV) dan Scaffolding-nya Berdasarkan Analisis Kesalahan Newman pada Siswa Kelas VIII SMP Negeri 2 Malang. Jurnal Pendidikan Matematika Dan Sains, 2(2), 109116. https://doi.org/10.21831/jpms.v4i2. 7161

Rahmawati, D., \& Permata, L. D. (2018). Analisis Kesalahan Siswa Dalam Menyelesaikan Soal Cerita Program Linear Dengan Prosedur Newman. Jurnal Elektronik Pembelajaran Matematika, 5(2), 173-185.

Rohmah, M., \& Sutiarso, S. (2018). Analysis problem solving in mathematical using theory Newman. Eurasia Journal of Mathematics, Science and Technology Education, 14(2), 671681. https://doi.org/10.12973/ ejmste/80630

Rr Chusnul, C., Mardiyana, \& Dewi Retno, S. (2017). Errors analysis of problem solving using the Newman stage after applying cooperative learning of TTW type. AIP Conference Proceedings, 1913(December 2017). https://doi.org/10.1063/1.5016662

Santoso, D. A., Farid, A., \& Ulum, B. (2017). Error Analysis of Students Working about Word Problem of Linear Program with NEA Procedure. Journal of Physics: Conference Series, 855(1). https://doi.org/10.1088/17426596/855/1/012043

Selçuk, G. S. (2010). The effects of problem-based learning on preservice teachers' achievement, approaches and attitudes towards learning physics. International Journal of Physical Sciences, 5(6), 711-723.
Sholeh, M., \& Sari, A. (2018). Proses Metakognisi Tahap Evaluation Siswa SMP Dalam Menyelesaikan Soal PISA. Jurnal Kajian Pembelajaran Matematika (JKPM), 2(1), 26-30. http://journal2.um.ac.id/index.php/j $\mathrm{kpm} /$ article/view/3234/2186

Sipayung, T. N., \& Anzelina, D. (2019). An analysis of students problem solving skills using a realistic mathematics approach on integers materials. Journal of Physics: Conference Series, 1211(1). https://doi.org/10.1088/17426596/1211/1/012083

Susanti, R. D., \& Taufik, M. (2019). Analysis Student Mistake of Teacher Professional Education In Completing Story Problems Based on Newman Procedures. International Journal of Trends in Mathematics Education Research, 2(2), 72. https://doi.org/10.33122/ijtmer.v2i2 .59

Tawfik, A. A., \& Lilly, C. (2015). Using a Flipped Classroom Approach to Support Problem-Based Learning. Technology, Knowledge and Learning, 20(3), 299-315. https://doi.org/10.1007/s10758015-9262-8

Yusri, A. Y. (2018). Pengaruh Model Pembelajaran Problem Based Learning Terhadap Kemampuan Pemecahan Masalah Matematika Siswa Kelas Vii Di Smp Negeri Pangkajene. Mosharafa: Jurnal Pendidikan Matematika, 7(1), 5162.

https://doi.org/10.31980/mosharafa. v7i1.341 